\title{
A rejtett gazdaság néhány területének szisztematikus szakirodalmi áttekintése
}

Tanulmányunkban a rejtett gazdaság szisztematikus szakirodalmi áttekintését kíséreltük meg közel száz magyarországi és nemzetközi mü feldolgozása alapján. A tanulmány három terület vizsgálatát tüzte ki célul: fogalmi megközelítések, a rejtett gazdaság kialakulásának okai és a rejtett gazdaság hatásai. Módszerünk egy adott terület szakirodalmának szisztematikus, teljes körü feldolgozása volt. Elmondható, hogy a közel negyven elnevezés és a számtalan fogalmi meghatározás nem teszi lehetővé egy egységes definíció megalkotását, ennek oka elsősorban az, hogy egy konkrét ország többéves áttekintésekor sem biztos, hogy ugyanazok a terminusok ugyanazokat az elemeket tartalmazzák. A rejtett gazdaság okai között leggyakrabban az adó- és járulékrendszer, az állami bürokrácia kiterjedtsége és hatékonysága, valamint a szabályozási környezet szerepelt. A rejtett gazdaság okai és hatásai szorosan összefüggnek, összetett hatást gyakorolva egymásra. Journal of Economic Literature (JEL) kód: E26.

\section{Bevezetés}

A rejtett gazdaság szakirodalmi áttekintésével elsődleges célunk az volt, hogy rendszerezzük, szintetizáljuk az elmúlt 40 évben megjelent - a későbbiekben meghatározott szempontok alapján kiválasztott - publikációkat. Kiválasztott témánkon belül három terület felülvizsgálatát végeztük el: fogalmi megközelítések, a rejtett gazdaság kialakulásának okai és a rejtett gazdaság hatásai.

Témaválasztásunkat alapvetően a következő tényezők indokolják:

1. a téma folyamatos aktualitása;

2. hiánypótlás, mivel a témában teljes körü szisztematikus szakirodalmi feldolgozás nem történt (1. ábra);

\footnotetext{
Fenyvesi Éva a Budapesti Gazdasági Egyetem Közgazdasági és Üzleti Tudományok Tanszék vezetője, KVI Kar tudományos dékánhelyettese (e-mail: fenyvesi.eva@uni-bge.hu).

Vágány Judit Bernadett a Budapesti Gazdasági Egyetem Közgazdasági és Üzleti Tudományok Tanszék oktatója (e-mail: Vagany.Judit@uni-bge.hu).

A kézirat első változata 2019. április 5-én érkezett szerkesztőségünkbe.

DOI: http://dx.doi.org/10.18414/KSZ.2020.5.512
} 
3. a szisztematikus irodalomfeldolgozás módszertanának magyar nyelven történő bemutatása;

4. egy párhuzamos kutatásunk két központi elemének (borravaló és feketemunka) keretbe helyezése.

1. ábra

A különböző típusú szakirodalmi áttekintések szükségessége a közzétett kutatások és a szakirodalmi áttekintések számának függvényében

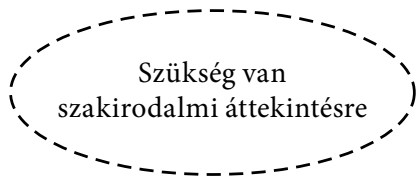

Szükséges a szakirodalmi áttekintések felülvizsgálata

A szakirodalmi áttekintések számossága

Forrás: Pautasso [2013] alapján saját szerkesztés.

Egy ilyen típusú szakirodalmi feldolgozásnak számos előnye van:

1. értékes lehet azok számára, akik a témában kutatnak, mivel egy helyen találják meg azt, hogy a különbözö tanulmányok mire helyezik a hangsúlyt, anélkül hogy maguknak kellene jelentős időt tölteni a releváns szakirodalom felkutatásával;

2. az adott tudományágon belüli tanulmányokról elfogulatlan információt nyújt az olvasónak;

3. segíthet annak eldöntésében, hogy a témában milyen területen szükségesek további kutatások.

\section{Módszer}

Módszerünk egy adott terület szakirodalmának szisztematikus, teljes körü feldolgozása. A vizsgálatba bevont cikkeket bizonyos - a későbbiekben bemutatott - felvételi és kizárási tényezők alapján határoztuk meg.

A szakirodalmi feldolgozás minőségi készítése az 1990-es években kezdte el foglalkoztatni a kutatókat. 1995-ben Daryl Bem egyik cikkében részletesen leírja, hogy milyen lépésekre kell figyelni, ha valaki a Psychological Bulletinbe szeretne egy szakirodalmi áttekintést készíteni Bem [1995]). Vagy például egy 1996-os egészségügyi konferencia kapcsán dolgozták ki a QUOROM metaelemzési szabványokat (The Quality of 
Reporting of Meta-analyses). Harminc klinikai szakembert, kutatót, statisztikust kértek fel, hogy készítsenek egy szabványosított modellt, amely tartalmaz minden olyan ellenörzési pontot, amelynek segítségével el lehet végezni egy metaelemzést, segítve az egészségügyi beavatkozások szisztematikus felülvizsgálatát. A QUOROM-ot később frissítették és átnevezték a „szisztematikus irodalomfeldolgozás és metaelemzés elönyben részesített elkészítési pontjaira" (Preferred Reporting Items for Systematic Reviews and Meta-Analyses, PRISMA) (Moher és szerzötársai [1999]).

A módszer azóta egyre inkább tért hódít más tudományterületeken is. Egy szakirodalmat áttekintő tanulmány (review artical) készítése nem azonos egy adott téma elméleti hátterének kidolgozásával, így például nem jelenti az adott témakörben található publikációk listáját vagy az ezekről készített rövid összefoglalót. A szakirodalmi áttekintés célja, hogy bemutassa a kiválasztott témában egy adott időszakban bekövetkező változásokat, és/vagy összefoglalja a téma aktuális ismereteit. Ezáltal az olvasó számára áttekintést nyújt a kutatási eredmények alakulásáról az adott területen.

Egy szakirodalmat áttekintő publikáció több elsődleges irodalom eredményeit szintetizálja, hogy koherens ismérveket mutasson be egy adott témáról vagy kutatási területről, hogy előre jelezze, milyen kutatási irányokra van szükség a vizsgált tudományágban. Bár a szakirodalmat áttekintő cikkek nem hoznak létre új kutatási eredményeket, ennek ellenére szinte mindig újszerü metaelemzést adnak az eredményekröl, amelyek új típusú rendszerezéshez és szintézishez vezetnek (Mack [2016]).

A szakirodalmi áttekintés nem szerző-, hanem fogalmi központú, ami meghatározza a felülvizsgálat keretét. Ezzel ellentétben azok a publikációk, amelyek szerzőközpontú megközelítést alkalmaznak, nem képesek az irodalom szintetizálására, lényegében csak összefoglalják a releváns cikkeket (Webster-Watson [2002]).

A szakirodalmat áttekintő publikációk lehetnek: 1. leírók, illetve szisztematikus, integratív áttekintések vagy 2. mini- vagy teljes felülvizsgálaton alapulók.

1. A leíró felülvizsgálatok az egyes tanulmányok módszertanára, megállapításaira és értelmezésére összpontosítanak. Az integratív áttekintések megpróbálják a közös ötleteket és fogalmakat megtalálni, illetve a bizonyítékon alapuló kutatási eredményeket összehasonlítani (Pautasso [2013], Cook-West [2012]).

2. Néhány folyóirat inkább az elmúlt évekre összpontosító, meglehetősen rövid vélemények közzétételét támogatja, korlátozva a szavak és idézetek számát (Pautasso [2013]).

A rejtett gazdaság szakirodalmának felülvizsgálatakor mi a fenti két megközelítésen belül a teljességre és a szisztematikusságra törekedtünk.

A szakirodalmi feldolgozás során a Pautasso [2013] által - 2013-ig 25 szakirodalmi áttekintés alapján - kidolgozott alábbi tíz szabályt használtuk útmutatónak:

1. a téma és célközönség meghatározása,

2. a szakirodalom keresése és újrakeresése,

3. jegyzetek készítése olvasás közben,

4. a publikáció típusának és elhelyezésének kiválasztása,

5. a felülvizsgálatra való összpontosítás mellett széles körű érdeklődés felkeltése,

6. a publikáció készítése közben kritikusságra és következetességre való törekvés, 
7. a megfelelő logikai szerkezet megtalálása,

8. visszajelzések kérése a publikációra vonatkozóan,

9. a saját releváns kutatások (amennyiben vannak ilyenek) felvétele a vizsgált adatbázisba az objektivitás betartása mellett,

10. a korábbi tanulmányok áttekintése mellett naprakészségre való törekvés.

Ahhoz, hogy az eredmények világosan bemutathatók legyenek, pontosan meghatároztuk a témán belül azoknak az írásoknak a körét, amelyekkel foglalkozni kívántunk. Ezért összegyüjtöttük az elemzésbe bevont szakirodalmakkal kapcsolatos felvételi és kizárási tényezőket.

1. A publikáció ellenőrizhetően tudományos értéke, azaz a megjelenés helyének behatárolása. Így a keresést elsősorban olyan adatbázisokban végeztük el, amelyek tudományos folyóiratokban megjelent cikkeket, könyveket, tanulmányokat gyüjtenek össze. A magyar nyelvü szakirodalom felkutatásához a Matarka (Magyar Folyóiratok Tartalomjegyzékeinek Kereshetö Adatbázisa), a Google Scholar és az Arcanum keresőbázist használtuk. Az idegen nyelvüekhez pedig a Google Scholar, a Web of Science és a ProQuest adatbázist alkalmaztuk.

2. Az elemzésbe bevont publikációk nyelve magyar és angol.

3. A teljes publikáció (közvetve vagy közvetlenül) elérhető legyen, ezt az elemzett területek (fogalmak, okok, hatások) tették szükségessé.

4. Terjedelmi korlátok miatt azon szerzők esetében, akik a témához kapcsolódóan kiemelkedő publikációs tevékenységet folytatnak/folytattak, elsősorban a kutatásunk szempontjából legrelevánsabb cikkeit választottuk ki.

Mint említettük, ma már számos adatbázis áll a rendelkezésünkre, hogy felleljük a kiválasztott témához kapcsolódó szakirodalmat. Esetünkben azonban több nehézség is felmerült. Egyrészt a kutatott területhez kapcsolódó kifejezésre igen sok elnevezés található. Ezenkívül egy-egy kifejezés számos más dologra is vonatkozhat, mint például a feketegazdaság (black economy), amely az angol nyelvü szakirodalomban túlnyomó többségben a fekete lakosság által müködtetett gazdaságra utal, és nem a rejtett gazdaságra.

Általánosságban elmondható, hogy a kezdetben több ezer, illetve tízezer szakirodalmi találat a szükítések hatására előbb-utóbb százas nagyságrendre vagy még kevesebbre csökkent. Például a hidden economy kifejezésre a Web of Science-ben 1091, a ProQuestben 353813 találat jelent meg. Az operátorok segítségével történő szűkítés, majd a szükített lista absztraktjainak elolvasása után végül 100-200 cikk maradt meg mint releváns szakirodalom. Hasonlóan a Google Scholarban a rejtett gazdaság kifejezés szövegben történő keresése szürés nélkül 8780 találatot eredményezett. Szürés után (ne legyen benne kastély, kincs, viszony stb.) 1100-ra csökkent ez a szám. Relevancia szerinti rendezés „első 200 helyezettjében” történő keresés után az eredmény 32 cikk lett. Ha a teljes listán belül a címben való keresését állítottuk be a Google Scholarban, 15 publikáció jelent meg a rejtett gazdaság kifejezésre.

Az 1. táblázatban bemutatjuk, hogyan állt össze a magyar nyelvü cikkek és a magyar szerzők angol nyelvü publikációinak „végleges” listája. A táblázatban 
szereplő adatbázisokban a felsorolásuk sorrendjében kerestünk. A duplikációkat nem, csak az új publikációkat vettük figyelembe. A három adatbázisban fellelt cikkeken kívül az e cikkek referenciáiban található hivatkozások alapján további 25 publikációval bővült a listánk.

\section{1. táblázat}

A kereső adatbázisokban a rejtett gazdaság kifejezésre talált magyar nyelvü és magyar szerzők angol nyelvü publikációinak száma

\begin{tabular}{lc}
\hline Adatbázis & Találatok száma \\
\hline Matarka & 16 \\
Arcanum & 11 \\
Google Scholar & 32 \\
A cikkek hivatkozásai & 25 \\
\hline
\end{tabular}

Forrás: saját szerkesztés.

\section{Eredmények}

\section{A rejtett gazdaság meghatározása}

A témában számos szakirodalomi mű látott napvilágot, a bennük olvasható megközelítések között igen jelentős eltérések vannak. Már az elnevezés körül sincs egységes álláspont. A különböző kutatásokban több mint 40 megnevezés fordul elő. Ezt a változatos képet a teljesség igénye nélkül a 2. táblázatban foglaltuk össze Williams [2004] egyik írása alapján. Magyarországon leggyakrabban a fekete, szürke, rejtett, második, árnyék és földalatti jelzőket használják.

Az elnevezések azonban számos esetben nem egymás szinonimái, hanem a különböző tartalmakat árnyalják. Ennek igazolására mutatunk be néhány, a témában ismert szerző tollából származó elnevezést és a hozzá tartozó meghatározást, majd kísérletet teszünk arra, hogy táblázatba foglalva összehasonlítsuk őket (3. táblázat). Az összehasonlítás alapjául az OECD [2002] kézikönyvben felsorolt kategóriákat választottuk; a kézikönyv szerint a „nem megfigyelt gazdaság” (Non-observed Economy, NOE) kifejezés azokra a gazdasági tevékenységekre utal, amelyeket be kell vonni a GDP-be, de amelyekre nem terjednek ki a statisztikai felmérések vagy adminisztratív nyilvántartások.

A nem megfigyelt gazdasági tevékenységek a következők lehetnek.

Háztartások saját termelö felhasználása, barterügyletek, kalákák stb.

Informális tevékenységek: törvényileg nem nyilvántartott vállalatok, a háztartások termelése saját felhasználásra.

Földalatti tevékenységek: a jövedelem, az adók, a járulékok kifizetésének, bizonyos jogi normáknak az elkerülése, például a minimálbér meg nem adása, a biztonsági vagy egészségügyi szabványok be nem tartása. 
2. táblázat

A szakirodalmakban fellelhető terminusok többsége

\begin{tabular}{|c|c|c|c|}
\hline Magyar & Angol & Magyar & Angol \\
\hline Adózatlan & Untaxed & Második & Second \\
\hline Árnyék & Shadow & Megvilágítatlan & Unexposed \\
\hline Éjjeli & Moonlight & Mellékes & Marginal \\
\hline Elmerült & Submerged & Mindennapos & Everyday \\
\hline Eltitkolt & Concealed & Nem hivatalos & Non-official, Unofficial \\
\hline Észrevétlen & Unobserved & Nem megfigyelt & Non-observed \\
\hline Fekete & Black & Nem rögzített & Off-the-books, Unrecorded \\
\hline Földalatti & Subterranean, Underground & Párhuzamos & Parallel \\
\hline Gettó & Ghetto & Periferikus & Peripheral \\
\hline Homály & Twilight & Rejtett & Hidden \\
\hline Ismeretlen & Occult & Szabályozatlan & Unregulated \\
\hline Készpénzes & Cash-in-hand & Szabálytalan & Irregular \\
\hline Kétes & Precarious & Szervezetlen & Unorganised \\
\hline Kettős & Dual & Szürke & Grey \\
\hline Láthatatlan & Invisible & Titkos & Clandestine \\
\hline Másik & Other & Vízalatti & Underwater \\
\hline
\end{tabular}

Forrás: saját szerkesztés Williams [2004] alapján.

Illegális tevékenységek: törvény szerint tiltott termékek és szolgáltatások előállítása, értékesítése vagy pusztán birtoklása; rendszerint nem legális előállítótól származó legális termelési tevékenységek.

Az általunk vizsgált szakirodalmak közül a legkorábbi meghatározást Edgar Feige fogalmazta meg: „A szabálytalan gazdaság olyan gazdasági tevékenységekre utal, amelyek nem bejelentettek, vagy amelyeket a társadalom jelenlegi gazdaságitevékenység-ellenőrzési technikái nem mérnek.” (Feige [1979] 6. o.) Azaz „ez a definíció magában foglalja mindazokat a tevékenységeket, amelyek a konvenció szerint kimaradnak a GDP számításából, valamint azokat, amelyek elkerülik a mérési folyamatot” (Lackó [1995] 486. o.).

Ilyen széles értelemben közelíti meg Lackó [2000] a földalatti gazdaságot, amely többféle gazdasági tevékenységet ölel fel. Idesoroljuk például a háztartások által saját célra előállított termékek és szolgáltatások termelését és cseréjét, a be nem jelentett munkát, illetve más illegális aktivitást és a bünügyi gazdasági tevékenységet.

Hasonlóan az előzőkhez a nem megfigyelt gazdaság Lackó és szerzőtársai [2009] és Murai-Ritzlné [2011] szerint lefedi a háztartások saját fogyasztásra való termelését, az informális és földalatti gazdaságot, valamint az illegális termelést. Ezekben a meghatározásokban már jól tükröződnek az OECD [2002] fogalmi definíciói.

A fogalmi meghatározások egy része nem tartalmazza a háztartások saját szükségletre való termelését, ezeket vesszük sorra. 


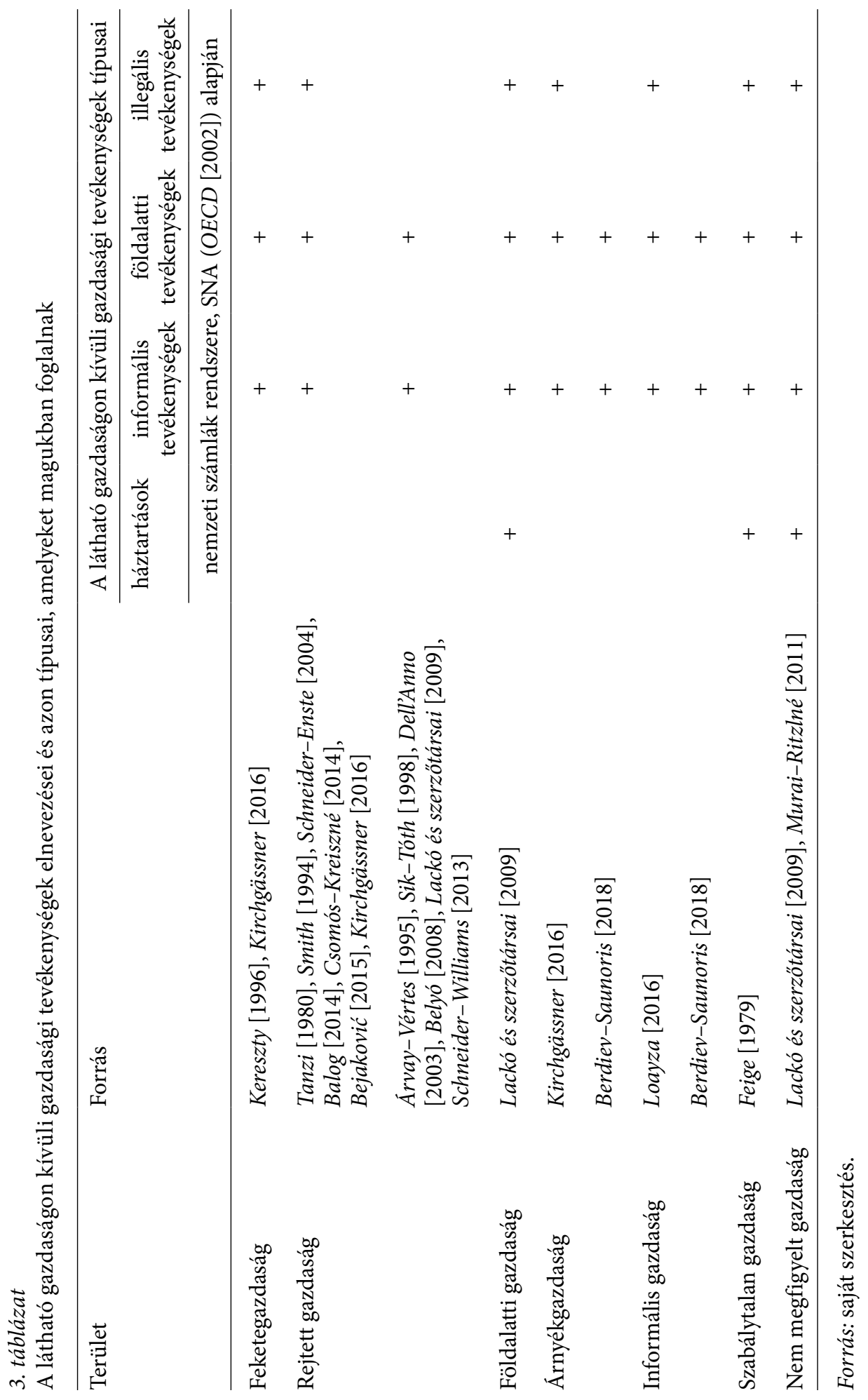


1. A Kereszty [1996] és Kirchgässner [2016] által körülírt feketegazdaság. Kereszty [1996] szerint a feketegazdaság három csoportból áll. Az első csoportba azok a tevékenységek tartoznak, amelyek egy adott gazdaságban tiltottak. Ilyenek lehetnek a kábítószer-, a fegyverkereskedelem, a piramisjáték stb. A második csoportba tartozó tevékenységek bár legálisak, a jövedelemszerzés azonban bűncselekmény - leggyakrabban vám- vagy adócsalás - útján történik. A harmadik csoportot azon legális vállalkozások, cégek legális tevékenységei alkotják, amelyek jogszabályt sértenek, mert az adórendszert valamilyen mértékben megkerülik. Kirchgässner [2016] szinonimaként használja a feketegazdaság, a földalatti gazdaság és a rejtett gazdaság kifejezéseket. Értelmezésében ezek minden olyan termelötevékenységet magukban foglalnak, amely - például adócsalás, rejtett munka, büncselekmény miatt - a hivatalos GDP-ben nem szerepel.

2. Tanzi [1980], Smith [1994], Schneider-Enste [2004], Balog [2014], CsomósKreiszné [2015], Bejaković [2015], Kirchgässner [2016] rejtett gazdaság meghatározása. Smith [1994] meghatározása szerint a rejtett gazdaságban olyan áruk és szolgáltatások piaci alapú előállítása zajlik, amelyek kimaradtak a GDP hivatalos becsléséből, akár legálisak, akár illegálisak. A Balog Ádám által használt meghatározás is azt „sugallja”, hogy a meghatározásába beleérti az illegális tevékenységeket is. A rejtett gazdaság része „minden olyan nem regisztrált tevékenység, amely hozzájárul a bruttó hazai össztermék előállításához" (Balog [2014] 16. o.). Bejaković [2015] szerint a „rejtett” gazdaságban végzett tevékenységek közé tartozik az áruk és szolgáltatások be nem jelentett - akár egyébként törvényes - termelése, az illegális áruk és szolgáltatások előállítása és a természetbeni jövedelmek elrejtése. Schneider-Enste [2004] meghatározása alapján a rejtett gazdaságba tartozik a jogellenes munkavállaláson keresztül a bünügyi gazdasági szektor tevékenysége is, de az egyéni szükségletekre irányuló nem piaci tevékenységek és a kölcsönös segítség nem tartozik bele, mert az elszámolási konvenciók alapján nem részei a GDP-nek, így a jövedelemelszámolásba sem tartoznak bele. Victor Tanzi úgy határozza meg a rejtett gazdaságot, mint „az a bruttó nemzeti termék, amely a nem bejelentett és/ vagy alulreprezentált adatok miatt nem szerepel a hivatalos statisztikákban" (Tanzi [1980] 428. o.). Más szerzők szerint a rejtett gazdaság csak azokat a tevékenységeket tartalmazza, amelyek a valós társadalmi igényeket kielégítő áruk és szolgáltatások elöállítását vagy értékét növelik. A korrupciót és a börtönbüntetéssel büntetendő egyéb cselekményekböl származó jövedelmet kizárták a rejtett gazdaság fogalmából (Árvay-Vértes [1995], Sik-Tóth [1998], Dell'Anno [2003], Belyó [2008], Lackó és szerzötársai [2009], Schneider-Williams [2013]).

3. Kirchgässner [2016] árnyékgazdasága (lásd 1. és 2. pont).

4. Loayza [2016] informális gazdaságon olyan cégek, munkavállalók és tevékenységek gyüjteményét érti, amelyek a jogi és szabályozási rendszereken kívül müködnek. A megfogalmazás általánossága miatt nem derül ki egyértelmủen, hogy az illegális tevékenységet is beleérti-e a szerző. Az informális gazdaság kifejezést BerdievSaunoris [2018] is használja (szinonimaként az árnyékgazdaság fogalmával), amelyen a jogi és szabályozási kereteken kívül müködö cégeket, munkavállalókat érti, de kizárja az illegális gazdaságot (például kábítószer-előállítás). 
Sik-Tóth [1998] rejtett gazdaság definíciója nem veszi figyelembe a háztartási munkát, a „csináld magad” tevékenységeket, a társadalmi munkát, a háztartások közötti termékcserét, a bünözést, a nem legális termelötevékenységeket (például drogok elöállítása és kereskedelme). Dell'Anno [2003], Belyó [2008], Lackó és szerzötársai [2009], Schneider-Williams [2013] - hasonlóan Berdiev-Saunoris [2018]-hoz - a rejtett gazdaságon azokat a gazdasági tevékenységeket érti, amelyek a kormányzati szabályozás, adóztatás kikerülésével keletkeznek.

\section{A rejtett gazdaság okai}

Egy ország rejtett gazdaságának mértéke erősen függ annak történelemi hátterétől. Emellett számos más tényező is szerepet játszhat létrejöttében, mint például az ország fejlettségi szintje, adókultúrája, adórendszere, jogrendszere és intézményrendszere. Mivel a felsorolt okok szoros összefüggésben állnak egymással, nehéz megállapítani hatásuk mértékét (Ékes [2003]). Ennek ellenére történtek kísérletek. Schneider-Williams [2013] szerint a legmagasabb befolyást az adók és a társadalombiztosítási járulékok mutatják (45-52 százalék), ezt kíséri az állami intézmények minősége (10-17 százalék), majd a munkaerőpiaci szabályozás, a transzferátutalások és a közszolgáltatások (7-9 százalék) következnek.

A feldolgozott szakirodalom alapján az adó- és járulékrendszer, az állami bürokrácia kiterjedtsége és hatékonysága, valamint a szabályozási környezet szerepel az első három helyen (4. táblázat). Ebből az adó- és társadalombiztosítási hozzájárulás, valamint az állami szabályozás mértéke (például munkaerőpiaci szabályok, kereskedelmi korlátok, bevándorlók munkavállalásának korlátozása) örökzöld téma, hisz az elmúlt 40 évben folyamatosan a vizsgálat középpontjába került. Az intézményi rendszer minőségének csökkenése, a fokozott bürokrácia mint a rejtett gazdaság oka a 21. századtól került a figyelem középpontjába.

\section{4. táblázat}

A rejtett gazdaság területei a feldolgozott szakirodalom alapján

Terület Forrás

Adók, társadalombiztosítás

Tanzi [1980], Enyedi-Tamási [1995], Bićanić-Ott [1997], Johnson és szerzőtársai [1998], Szántó-Tóth [2001], Ékes [2003], SemjénTóth [2004], Dreher és szerzőtársai [2005], Williams [2004], Sisak [2007], Dell'Anno-Solomon [2008], Schneider [2009], Thiessen [2010], Schneider és szerzőtársai [2011], Schneider-Williams [2013], Balog [2014], Benke-Karcagi-Kováts [2017]

A közszféra mérete, $\quad$ Ékes [2003], Dreher és szerzőtársai [2005], Sisak [2007], az állami intézmények Schneider [2009], Semjén-Tóth [2009], Torgler-Schneider [2009], minősége

Dreher-Schneider [2006], [2010], Schneider-Williams [2013], AlmEmbaye [2013], Petreski [2014], Bayar [2016] 
A 4. táblázat folytatása

\begin{tabular}{ll}
\hline Terület & Forrás \\
\hline Szabályozási környezet & Tanzi [1980], Johnson és szerzötársai [1998], Dreher és szerzötársai \\
& [2005], Williams [2004], Sisak [2007], Kucera-Roncolato [2008], \\
& Dell'Anno-Solomon [2008], Schneider [2009], Thiessen, [2010], \\
& Schneider és szerzötársai [2011], Schneider-Williams [2013], \\
& Balog [2014], Petreski [2014], Benke-Karcagi-Kováts [2017]
\end{tabular}

Adómorál

Enyedi-Tamási [1995], Szántó-Tóth [2001], Williams [2004], Sisak [2007], Schneider [2009], Schneider-Williams [2013], Balog [2014]

Korrupció

Antal [1995], Dreher és szerzötársai [2005], Lackó [2006], Virta [2007], Balog [2014], Enyedi-Tamási [1995], Williams [2004], Schneider [2007], Dreher-Schneider [2006], [2010], Belyó [2012], Manolas és szerzőtársai [2013]

Közjavak mennyisége, Bićanić-Ott [1997], Johnson és szerzötársai [1998], minősége Dell'Anno-Solomon [2008], Schneider [2009], Schneider és szerzőtársai [2011], Schneider-Williams [2013], Balog [2014]

Párhuzamos fizetési módok Bićanić-Ott [1997], Schneider [2009], Schneider-Williams [2013]

Gazdaság állapota (konjunktúra, dekonjunktúra)

Az igazságszolgáltatás gyengesége, joghézagok

Háború, válság

Piacgazdaságra való átmenet

Kényszer-mikrovállalkozások, egyéni vállalkozók

Közoktatási kiadások, oktatási színvonal

A népesség egyenlőtlen eloszlása

Szolgáltatási szektor növekedése

Infláció

Értékrend

Privatizáció

Elszegényedés
Schneider [2009], Schneider és szerzőtársai [2011], Bićanić-Ott [1997], Dell'Anno-Solomon [2008]

Ékes [2003], Fekete és szerzőtársai [2008], Enyedi-Tamási [1995], Bićanić-Ott [1997], Torgler-Schneider [2009], Thiessen [2010]

Bićanić-Ott [1997]

Schneider és szerzőtársai [2010], Bayar [2016]

Enyedi-Tamási [1995], Bićanić-Ott [1997], Ékes [2003], Benke-Karcagi-Kováts [2017]

Enyedi-Tamási [1995],

Kleven és szerzőtársai [2011]

Williams [2004], Berrittella, [2015]

Buehn [2011]

Ékes [2003]

Bićanić-Ott [1997], Ékes [2003]

Enyedi-Tamási [1995], Thiessen [2010]

Enyedi-Tamási [1995]

Enyedi-Tamási [1995], Ékes [2003]

Forrás: saját szerkesztés. 
Az ADÓK, A TÁRSADALOMBIZTOsíTÁs mérete többek között a munkaerő munka- és szabadidő közötti választásán és a gazdaságban való részvétellel kapcsolatos döntésein keresztül fejti ki hatását, azaz minél nagyobbak a terhek, annál inkább ösztönzik a munkaerőt az árnyékgazdaságban való munkavállalásra (Schneider [2009]). Johnson és szerzőtársai [1998], majd 15 évvel később Schneider-Williams [2013] statisztikailag szignifikáns bizonyítékot talált az adózás árnyékgazdaságra való hatására. Balog [2014] szerint a láthatóságot az adórendszer egyszerűsítésével lehet növelni. Az egyszerübb adórendszerek egyrészt csökkentik az adófizetés járulékos költségeit (bevallás, szabályértelmezés), ami csökkentheti az adóelkerülésben való részvétel relatív hozamát. Ezenkívül mérsékeli az ellenőrzés költségeit, s ez adott ellenőrzési kiadás mellett növelheti az ellenőrzés kiterjedését és így a lebukás valószínűségét.

A SZABÁLYOZÁSI KÖRNYEZET intenzitásához tartoznak a munkaerőpiaci szabályozók, a kereskedelmi korlátok (importkvóták), a külföldi munkavállalókra vonatkozó munkaerőpiaci korlátozások (Schneider [2009], Schneider és szerzőtársai [2011]). Kucera-Roncolato [2008] mindezekből a munkaerőpiaci szabályozás többféle formáját emeli ki (például minimálbér, kompenzációs követelmények, szakszervezeti tevékenység). Semjén-Tóth [2009] azt hangsúlyozza, hogy a rejtett gazdaság kialakulásának egyik fö indoka maga az állam nem megfelelő müködése, hiszen annak hátterében valamilyen szabályozási kudarc áll. Azonban ez fordítva is igaz, az állam a modern gazdaságokban nem hagyhatja a piac müködését csupán a piaci mechanizmusokra. Így a kormányzati beavatkozás a piackudarc léte miatt következik be.

A KÖZSZFÉrA MÉRETE, AZ ÁllAMi INTÉZMÉNYEK MiNősÉGE. A rejtett gazdaság növekvő méretének oka lehet a közszféra mérete. A túlburjánzó közigazgatás csak magas adók révén tartható fenn, aminek eredményeként egyre többen próbálnak kibújni az adófizetési kötelezettség alól (Sisak [2007]). Petreski [2014] a rejtett gazdaság okainak kutatása kapcsán negatív korrelációt mutatott ki az üzleti szempontból kedvezőbb szABÁLYOzÁs, az állami intézmények minőségi növekedése és az árnyékgazdaság nagysága között.

A 4. táblázat következő három blokkjában az adómorál, a korrupció, a közjavak és szolgáltatások minősége szerepel, s bár a feldolgozott irodalom alapján nem dobogós helyen, meghatározó tényezői a rejtett gazdaság kialakulásának.

Az AdómoráL mint a rejtett gazdaság nagyságát befolyásoló tényező elsősorban magyar szerzők publikációiban jelenik meg. Sisak [2007] úgy véli, hogy talán a legfontosabb oka a rejtett gazdaság növekedésének az adómorál gyengesége. A magas adómorál egyértelmüen csökkenti a rejtett gazdaság méretét, mert az adózó az adócsalás relatív hozamától függetlenül nem vesz részt a feketegazdaságban (Balog [2014]).

Kor RU PCIÓ. „A korrupció közvetlen hatását a különböző látható munkapiaci szegmensek alakulására (foglalkoztatás, önfoglalkoztatás, munkanélküliség) érdekes módon nem vizsgálják, a korrupciót csak a rejtett (nem hivatalos) gazdaság elemzésében veszik figyelembe, mint komoly súlyú hatótényezőt.” (Lackó [2006] 965. o.) A korrupció a rejtett gazdaságra épül, ahol széles a feketegazdaság, szükségszerüen széles a korrupció is (Antal [1995]).

A korrupció és a rejtett gazdaság közötti kapcsolat vizsgálata során születtek talán a legellentmondóbb eredmények. Dreher-Schneider [2006], [2010] kimutatta, hogy 
nincs statisztikailag szignifikáns kapcsolat az árnyékgazdaság és a korrupció között. Schneider [2007] árnyaltabban fogalmazott: a korrupció negatívan befolyásolja az árnyékgazdaságot a magas jövedelmü, míg pozitívan befolyásolja az alacsony jövedelmü országcsoportokban. Virta [2007] szerint a korrupció pozitív hatással van az árnyékgazdaság nagyságára, míg Manolas és szerzőtársai [2013] úgy véli, a korrupció negatív hatással van az árnyékgazdaság nagyságára. Belyó Pál úgy véli, „,a rejtett gazdaság mérete és a korrupció mértéke egyenes arányban áll egymással, és erös köztük a konzisztens korreláció. Azok az országok, ahol több a korrupció, ceteris paribus nagyobb rejtett gazdasággal rendelkeznek. A korrupció visszaszorításával gyengül a rejtett gazdaság." (Belyó [2012] 32. o.)

A KÖZJAVAK MENNYISÉGE ÉS MINŐSÉGE. Bićanić-Ott [1997] szerint a rejtett gazdaság tíz tényezője között a közszféra szolgáltatásának alacsony színvonala is szerepel. Ezt Johnson és szerzőtársai [1998] is így véli, amit a szerzők azzal indokolnak, hogy az árnyékgazdaság növekedése az állami bevételek csökkenéséhez vezethet, ami csökkenti a közjavak minőségét és mennyiségét. Balog [2014] szerint az állam müködésének hatékonysága jelentősen befolyásolja a rejtett gazdaság méretét, mivel az alacsony színvonalú állami szolgáltatások rontják a befizetett adókért várható hasznosságértéket, így jobban ösztönöznek az adóelkerülésre.

A „HIVATALOS” GAZDASÁG ÁLlAPOTA. A rejtett gazdaságot nagyban befolyásolja, hogy a gazdaság éppen a konjunktúra vagy dekonjunktúra állapotában van-e (Schneider és szerzőtársai [2011], Schneider [2009]). Bayar [2016] a közigazgatás és az árnyékgazdaság különböző mutatói közti kapcsolatot vizsgálta 11 kelet-közép-európai gazdaságban a 2003-2014 közötti idöszakban. Megállapításai között szerepel, hogy a válságok kedvezően hatottak az árnyékgazdaságra. Dell'Anno-Solomon [2008] szerint a gazdasági visszaesés során különösen a munkanélküliségi ráta növekedése káros, mivel lehetővé teszi az informális szektorban való munkát. Csábító alternatíva az egyének számára, akik a hivatalos szektorról a nem hivatalosra váltanak.

Az IgAZsÁgszolgáltatÁs GYeNGeséGe, JOGHÉZAGOK. Torgler-Schneider [2009] a kormányzati hatékonyság, az elszámoltathatóság és a szabályozási minőség mellett a jogállamiság hiányosságait tartja felelősnek az árnyékgazdaság növekedésében. A feketegazdaság kézenfekvő okának Fekete és szerzőtársai [2008] is a gazdasági igazságszolgáltatás gyengeségét tartja. A szerzők szerint ez mindenekelőtt az eljárások hihetetlen lassúságával függ össze. Példaként említik az érdemi gazdasági perek sok évig történő elhúzódását.

A PIACGAZDASÁgRA VALÓ ÁTMENET. Vannak gazdaságok, ahol a rejtett gazdaság „szerves” része az ország müködésének. Például a rendszerváltás előtti Magyarországon nem jöhetett volna létre ilyen mértékü ,jólét”, ha a lakosság egy része nem kezd el ügyeskedni (fusizni, feketézni, maszekolni stb.) (Ékes [2003], BenkeKarcagi-Kováts [2017]).

ÉRTÉKREND. A különbözö tanulmányok kimutatták, hogy az alkotmányos szempontok, az adózás, a társadalombiztosítás és az adminisztratív terhek, a közigazgatás minősége, a gazdasági intézmények és az igazságszolgáltatási rendszer, az erkölcsi szempontok és értékek az árnyékgazdaság meghatározó tényezői (Thiessen [2010]). A rejtett gazdaság tehát szorosan összefügg az alapvető társadalmi kérdésekkel. 
Torzítja a társadalom elfogadott értékrendjét, csökkenti a társadalmi szolidaritást. A feketegazdaság nemcsak a gazdaság betegsége, hanem a társadalomé is. A gyógyításhoz nélkülözhetetlen diagnózis felállításakor, vagyis az alapvető okok keresésekor el kell szakadnunk a közismert olcsó szlogenektől, mint például attól, hogy kizárólag a magas adóterhekre fogjuk rá a feketegazdaság kialakulásának és újratermelődésének indítékát (Fekete és szerzőtársai [2008]). Enyedi-Tamási [1995] több más tényezö mellett az ideológiai és pszichikai tényezőket említi a rejtett gazdaság kialakulásának okaként. Ilyen a „polgári egoizmus” (hogy mindenki maga dönti el, mire akarja költeni az általa megtermelt pénzt, és nem akar számára nem kívánatos célokat támogatni) és a növekvő individualizmus, a csökkenő közösségi szellem.

A felsoroltakon kívül néhány kevésbé kutatott okra is hivatkoznak szerzők. Például Buehn [2011] szerint a népesség országos egyenlötlen eloszlása miatt a NÉPSÜRÜsÉG is meghatározó tényezőnek számít, azaz a népsürüség és az árnyékgazdaság között negatív kapcsolat van. Az alacsony népsürüségü, tipikusan vidéki vagy határ menti régiókban nem nyújtanak annyi foglalkoztatási lehetöséget, mint a nagyobb népsürüségü régiókban. Vagy Berrittella [2015] a KözoKTATÁsI KIADÁsoK nagysága és az árnyékgazdaság között állapított meg negatív kapcsolatot.

\section{A rejtett gazdaság hatásai}

A rejtett gazdaság hatásaival összességében kevesebb publikáció foglalkozik, mint annak okaival. A cikkekben leginkább kiemelt okok más cikkekben (vagy akár ugyanazon cikken belül) mint hatások jelennek meg, ami jól szemlélteti, hogy ez egy olyan körforgás, ahol nehezen választhatók szét az okok és hatások. A legtöbb feldolgozott publikáció a negatív következményeket emeli ki, de találunk példákat a rejtett gazdaság pozitív hatásaira is, illetve egyazon tényező mindkét helyen való szerepeltetésére. Ez utóbbira példa a gazdasági növekedés kétértelmü kapcsolata az árnyékgazdasággal. Az árnyékgazdaság egyrészt lassíthatja a gazdasági növekedést, mivel az informális szektor miatt kisebbek az adóbevételek. Másrészt az árnyékgazdaság ösztönzi a gazdasági növekedést a hivatalos szektorral való szinergián keresztül (Goel és szerzőtársai [2019]). Buehn [2011] szintén a gazdasági növekedés és az árnyékgazdaság közötti kapcsolat ellentmondásaira hívja fel a figyelmet. Egyrészt, elösegíti egy adott régió gazdagságának a növekedését, munkalehetőséget kínál a helyi lakosság számára. Másrészt, a jólét és az árnyékgazdaság szintje közötti kapcsolat negatív, mivel a növekvő árnyékgazdaság csökkentheti az adóbevételeket, ami alacsonyabb mennyiségü és minőségi közszolgáltatáshoz vezet, és ennélfogva alacsonyabb növekedési ütem várható.

A rejtett gazdaság negatív hatásait az 5. táblázatban foglaltuk össze. Az egyik legfőbb negatív következmény az állami költségvetésre gyakorolt hatás, azaz kormányzati bevételek csökkenése. Számos szerző hangsúlyozza, hogy az adókból származó bevételek csökkenése rontja a közjavak minőségét és mennyiségét, ami növekedéshez vezethet a hivatalos szektorban müködő cégek és magánszemélyek adókulcsaiban (Bejaković [2015], Balog [2014], Sisak [2007], Mara [2011], Berrittella [2015], 
Enyedi-Tamási [1995]). Ez egyre növeli a jövedelemkülönbséget a rejtett gazdaságban és azon kívül dolgozók között (Enyedi-Tamási [1995]). A be nem jelentett jövedelemmel rendelkezők pedig potyautasként vesznek részt az újraelosztási rendszerben (Sisak [2007]).

\section{5. táblázat}

A rejtett gazdaság negatív hatásai

\begin{tabular}{ll}
\hline A rejtett gazdaság negatív hatásai & Szerzők \\
\hline A kormányzati bevételek csökkenése & Dell’Anno és szerzőtársai [2007], \\
& Buehn [2011], Mara [2011], Belyó [2012], \\
& Balog [2014], Berrittella [2015]
\end{tabular}

Az adókulcsok növekedése és ezáltal a legális gazdaságban dolgozók adóterhének emelkedése

Sisak [2007], Mara [2011], Balog [2014],

A közjavak minőségének csökkenése

Bejaković [2015]

A hivatalos mutatók torzulása

Buehn [2011], Mara [2011], Balog [2014], Bejaković [2015], Berrittella [2015]

A hivatalos mutatók torzulása

Dell’Anno és szerzőtársai [2007], Sisak [2007], Belyó [2012], Balog [2014]

A tisztességes verseny feltételeinek romlása

A teljes foglalkoztatás akadályozása

Enyedi-Tamási [1995], Belyó [2012],

Berrittella [2015]

A termelékenység csökkenése

Berrittella [2015]

Sisak [2007], Berrittella [2015]

A döntéshozókban való bizalom csökkenése

Berrittella [2015]

A korrupció növekedése

Környezetszennyezés

(Válság idején) jövedelempótlásra motiválja az embereket

Növeli a lakásárakat

Az adómorál csökkenése

Rombolja a társadalmi erkölcsöt

Befolyásolja a beruházási döntéseket

Pontatlanul tükrözi a bérek, jövedelmek eloszlását

Mara [2011], Belyó [2012], Berrittella [2015]

Mara [2011], Berrittella [2015]

Sisak [2007], Viksne-Mazure [2011]

Növeli a bűnözést

Kiszolgáltatottabbá teszi a munkavállalókat

Az életminőség csökkenése

Georgiu [2013]

Belyó [2012]

Kereszty [1996], Sisak [2007], Mara [2011]

Sisak [2007], Belyó [2012]

Enyedi-Tamási [1995], Sisak [2007], Balog [2014]

Enyedi-Tamási [1995], Berrittella [2015], Mara [2011]

Enyedi-Tamási [1995]

Krieenko-Nevzorova [2015]

Forrás: saját szerkesztés.

A rejtett gazdaság „erkölcsi hatásai sem elhanyagolhatók: a szabad piacgazdaság és a szabad piaci verseny alapvető szabályai ellen hatnak. [...] A rejtett gazdasági tevékenységből származó bevételek felboríthatják a gazdaság, a politika és akár az erőszakszervezetek egyensúlyát, ami egy ország vagy egy egész régió destabilizációjához 
vezethet." (Belyó [2012] 27. o.) Az árnyékgazdaságnak tehát erős társadalmi hatása van (Kereszty [1996]). Szorosan kapcsolódik számos olyan jelenséghez, mint a korrupció, a különböző típusú büncselekmények, a kábítószer-kereskedelem, a maffiaszervezetek, a munkaerő-kizsákmányolás, a pénzmosás, az emberijog-sértések, a környezetszennyezés (Mara [2011], Berrittella [2015], Enyedi-Tamási [1995]).

A rejtett gazdaság gazdaságpolitikai szempontból is kedvezőtlen, mivel torzítja a gazdasági mutatókat (növekedés, munkanélküliség, jövedelemelosztás, infláció stb.) (Sisak [2007], Balog [2014]), a minek következtében a különböző kormányok nem megfelelő makrogazdasági stratégiát alakítanak ki (Dell'Anno és szerzőtársai [2007], Balog [2014]). Ez pedig a politikai döntéshozók hitelességének elvesztését vonja maga után (Berrittella [2015]). Mikroökonómiai szempontból csökkenti a vállalatok közötti tisztességes versenyt, akadályozza a teljes foglalkoztatást, és a termelékenység viszszaesését okozza (Berrittella [2015]). Nehezíti, ellehetetleníti a „leghatékonyabb” vagy legjobb ár-érték arányú megoldások felkutatását azáltal, hogy növeli a költségeket, miközben csökkenti a nyereséget, ezzel befolyásolva a beruházási döntéseket (Belyó [2012]). Az adóelkerülés miatt kieső adóbevételek következtében az állami beruházásokból is kevesebbet lehet végrehajtani (Sisak [2007]).

Krieenko-Nevzorova [2015] szerint az árnyékgazdaságnak a lakosság életminőségére gyakorolt hatását jelenleg nem vizsgálják kellőképpen. Az árnyékgazdaság különbözö hatással van az életszínvonalra (mivel az árnyékgazdaságban termelt jövedelem növeli a teljes bevételt) és az élet minőségére (a munkavégzés feltételei, egészség, biztonság stb.), azaz az árnyékgazdaság pozitívan hat az életszínvonalra, de negatívan befolyásolhatja az életminőséget. Enyedi-Tamási [1995] is kiemeli a feketefoglalkoztatás életminőségre gyakorolt negatív következményeit (fizetett szabadság, társadalombiztosítás stb. hiánya).

Az árnyékgazdaság negatív hatásait néhány szerző egy adott területre vonatkozóan vizsgálta meg. Például Pavicevic [2014] kimutatta, hogy hosszú távon az árnyékgazdaság növekedése hátrányosan érinti az idegenforgalmi ágazatot. Míg Georgiu [2013] elemzése arra hívja fel a figyelmet, hogy az árnyékgazdaság megnöveli a lakásárakat, ezáltal torzítja az ingatlanpiacot.

Egyes szerzők szerint a kedvezőtlen hatások mellett a rejtett gazdaságnak pozitív mellékhatásai is vannak (6. táblázat). Például mérsékli a gazdasági és politikai sokkokat, a nem hivatalos szférában végzett üzleti tevékenységek rugalmasabban alkalmazkodnak az aktuális gazdasági helyzethez, elnyelik a hivatalos gazdaságból kiszorult munkanélküliek egy részét, és hozzájárulnak a termékpaletta bővítéséhez (Sisak [2007], Mara [2011], Enyedi-Tamási [1995]). A rejtett gazdaság azáltal tompítja a gazdasági növekedés ciklikusságát, hogy a hivatalos gazdaság visszaesése a rejtett gazdaságba kényszerít számos munkavállalót, így a rejtett gazdaság munkaerőpiaca kisimítja a jövedelmek időbeli ciklikusságát. Annál fontosabb szerepet tölt be az egész nemzetgazdaságban, minél kevésbé rugalmasan tud a hivatalos gazdaság reagálni a különböző külső sokkokra (Sisak [2007]). Az informális szektor úgy is segíti a gazdasági növekedést, hogy hozzájárul a piacok létrehozásához, a pénzügyi források növeléséhez és a vállalkozói szellem fokozásához (Asea [1996]). 
6. táblázat

A rejtett gazdaság pozitív hatásai

A rejtett gazdaság pozitív hatásai

Forrás

A gazdasági növekedést elösegíti

Enyedi-Tamási [1995], Sisak [2007],

Schneider [2008], Goel és szerzőtársai [2019]

A foglalkoztatást növeli, ezzel bevételi forráshoz Belyó [1999], Sisak [2007], Enyedi-Tamási juttatja a lakosságot

[1995], Kriston [2014]

Segíthet a piacgazdaságok felé való átmenetben Štulhofer [1999], Glinkina [1999]

Az árak gyorsabban reagálnak a kereslet-kínálat Sisak [2007], Enyedi-Tamási [1995] változásaira

Hozzájárul a pénzügyi források növeléséhez

Asea [1996]

Hozzájárul a vállalkozói szellem fokozásához

Asea [1996]

Növeli az adóbevételt (közvetve)

Schneider [2008]

Hozzájárul a piacok létrehozásához

Asea [1996]

Bizonyos szolgáltatások olcsóbbá válnak

Sisak [2007]

Forrás: saját szerkesztés.

A kedvezö hatások között gyakran emelik ki, hogy a rejtett gazdaságban szerzett jövedelmek nagy részét a legális gazdaságban költik el. Schneider [2008] szerint ez a rejtett gazdaságban termelt jövedelmek 66 százaléka. További pozitív hatásként említik, hogy a rejtett gazdaság számos embernek biztosít munkalehetőséget, ezáltal jövedelmet. Így mérsékeli az elszegényedést (Sisak [2007], Enyedi-Tamási [1995]). Belyó [1999] szerint azokban a fejlődő országokban, ahol magas a munkanélküliség, a rejtett gazdaságban való részvétel létszükséglet a lakosság számára. Emellett úgy is hozzájárul az életszínvonal növekedéséhez, hogy számos szolgáltatás olcsóbb, mint a hivatalos gazdaságban, így többek számára elérhetővé válik (például cipész, autószerelö) (Sisak [2007]). Mindezeken felül a rejtett gazdaság segíthet a piacgazdaságok felé való átmenetben is (Štulhofer [1999], Glinkina [1999]).

\section{Következtetések, összefoglalás}

A rejtett gazdaság témakörében feldolgozott szakirodalom a terminusok használatában és azok meghatározásában igen heterogén. A definiálás nehézsége többek között abból is fakad, hogy ezek a fogalmak elsősorban egy adott gazdaságban, illetve egy adott időszakban értelmezhetők. Még a nemzeti számlák rendszerének (System of National Accounts, SNA) állandó fejlesztése miatt szükségessé vált közös szóhasználat és az egységes értelmezés sem hozta meg azt az eredményt, hogy a témában írott publikációk mindegyike használja azokat. Mindemellett a „legalitás” értelmezése is nagyon különböző. Például a tevékenységek legális vagy illegális volta az egyes országok jogszabályain alapul, amelyek eltérhetnek egymástól. Ezért az illegális tevékenység statisztikai megfigyelésével kapcsolatban számos nehézség merül fel (Sárkány [2014]). 
A rejtett gazdaság kialakulásának leginkább említett okai között az adó- és járulékrendszert, az állami bürokrácia kiterjedtségét és hatékonyságát, valamint a szabályozási környezetet említik, majd ezt követi az adómorál, a korrupció, a közjavak és szolgáltatások minősége. Az okok rejtett gazdaságra való kedvező vagy kedvezőtlen hatásának leírásában viszonylag nagy az egyezőség, kivéve a korrupció és a rejtett gazdaság kapcsolatával kapcsolatos megállapításokat: a kutatási eredmények között egyaránt megtalálható a „nincs szignifikáns kapcsolat”, „a korrupció »negatív«, illetve "pozitív« hatást gyakorol a rejtett gazdaságra" állítás.

Számos publikáció foglalkozik a rejtett gazdaság negatív és pozitív hatásaival, amelyekből két dolgot emelünk ki. 1. Igen gyakran szerepelnek a rejtett gazdaság hatásai között olyan tényezők, a melyek az okok között is szerepelnek (korrupció, adózás, közjavak minősége stb.). Mindez arra utal, hogy a gazdaság rejtett oldalát igen bonyolult, nehezen kibogozható, kölcsönösen egymást erősítö összefüggések jellemzik. 2. A rejtett gazdaság és a gazdasági növekedés kettős kapcsolata. A szakirodalom szerint a rejtett gazdaság egyik irányból támogatja a gazdasági növekedést, mivel hozzájárul új piacok létrehozásához, számos gazdasági szereplő számára munkát és jövedelmet biztosít, amelynek nagy részét a legális gazdaságban költik el. Másik irányból a rejtett gazdaság az eltitkolt jövedelmeken, adókon, járulékokon keresztül csökkenti az adóbevételek nagyságát, a közjavak mennyiségét és minőségét.

A téma szisztematikus szakirodalmi feldolgozása nem zárul le a rejtett gazdaság e tanulmányban bemutatott elemzésével. A továbbiakban a szakirodalom és a vonatkozó jogszabályok áttekintésén keresztül a rejtett gazdaság magyar vonatkozásait vizsgáljuk, különös tekintettel a feketemunkára és a borravalóra a vendéglátásban.

\section{Hivatkozások}

Alm, J.-Embaye, A. [2013]: Using dynamic panel methods to estimate shadow economies around the world, 1984-2006. Public Finance Review, Vol. 41. No. 5. 510-543. o. https:// doi.org/10.1177/1091142113482353.

Antal LÁszló [1995]: Korrupció és rejtett gazdaság. Tarnói Gizella interjúja. Mozgó Világ, 21. évf. 1. sz. 24-28. o.

Árvay János-VÉrtes András [1995]: The share of the private sector and the hidden economy in Hungary. GKI Economic Research Company, Budapest.

AsEA, P. K. [1996]: The Informal Sector: Baby or Bath Water? Carnegie-Rochester Conference Series on Public Policy, Vol. 45. 163-171. o. https://doi.org/10.1016/s0167-2231(96)00022-x .

BALOG ÁDÁm [2014]: Adóelkerülés és rejtett gazdaság Magyarországon. Köz-gazdaság, 9. évf. 4. sz. 15-30. o. https://www.mnb.hu/letoltes/balog-15-30.pdf.

BAYAR, Y. [2016]: Public governance and shadow economy in Central and Eastern European countries. Administratie si Management Public, Vol. 27. 62-73. o. http://www.ramp.ase. ro/en/_data/files/articole/2016/27-04.pdf.

BEJAKović, P. [2015]: A revision of the shadow economy in Croatia: causes and effects. Economic Research, Vol. 28. No. 1.422-440. o. https://doi.org/10.1080/1331677x.2015.1059104.

BELYó PÁL [1999]: Kísérletek a rejtett gazdaság nagyságának meghatározására. A gazdaságelemzés módszerei. Ecostat, Budapest. 
BELYó PÁl [2008]: A rejtett gazdaság nagysága és jellemzői. Statisztikai Szemle, 86. évf. 2. sz. 113-137. o.

BELYó PÁL [2012]: A rejtett gazdaság előretörése az új gazdaságpolitikai gyakorlat következtében. XXI. század - Tudományos Közlemények, 27. Általános Vállalkozási Főiskola, 25-46. o.

BEM, D. J. [1995]: Writing a review article for Psychological Bulletin. Psychological Bulletin, Vol. 118. No. 2. 172-177. o. https://doi.org/10.1037/0033-2909.118.2.172.

Benke GrétA-KarCAgi-Kováts AndReA [2017]: Szándék és valóság - egy attitűdvizsgálat eredményei a rejtett gazdaságról. Taylor, gazdálkodás- és szervezéstudományi folyóirat, 9. évf. 3-4. sz. 116-125. o. http://acta.bibl.u-szeged.hu/55005/.

Berdiev, A. N.-Saunoris, J. W. [2018]: Does globalisation affect the shadow economy? The World Economy, Vol. 41. No. 1. o. https://doi.org/10.1111/twec.12549.

Berrittella, M. [2015]: The Effect of Public Education Expenditure on Shadow Economy: A Cross-Country Analysis. International Economic Journal, Vol. 29. No. 4. 527-546. o. https://doi.org/10.1080/10168737.2015.1081259.

BićAnić, I.-Oтт, K. [1997]: The Unofficial Economy in Croatia: Causes, Size and Consequences. Occasional Paper, No. 3. Institute of Public Finance, Zágráb.

Buenn, A. [2011]: The Shadow Economy in German Regions: An Empirical Assessment. German Economic Review, Vol. 13. No. 3. 275-290. o. https://doi.org/10.1111/j.1468-0475.2011.00557.x.

Cook, D. A.-WEst, C. P. [2012]: Conducting systematic reviews in medical education: a stepwise approach. Medical Education, Vol. 46. No. 10. 943-952. o. https://doi.org/10.1111/ j.1365-2923.2012.04328.x.

Csomós BALÁzs-Kreiszné HudÁk Emese [2015]: A rejtett gazdaság mértékének csökkentése Magyarországon. MNB/Kiadványok/Szakmai cikkek, https://www.mnb.hu/letoltes/ csomos-balazs-kreiszne-hudak-emese-a-rejtett-gazdasag-mertekenek-csokkentesemagyarorszagon.pdf.

Dell'Anno, R. [2003]: Estimating the Shadow Economy in Italy: A Structural Equation Approach. Working Paper, No. 7. Department of Economics, University of Aarhus, Aarhus, 1-37. o.

Dell'Anno, R.-Solomon, O. H. [2008]: Shadow economy and unemployment rate in USA: Is there a structural relationship? An empirical analysis. Applied Economics, Vol. 40. No. 19. https://doi.org/10.1080/00036840600970195.

Dell'Anno, R.-Gómez, A.-Pardo, A. A. [2007]: The shadow economy in three Mediterranean countries: France, Spain and Greece. A MIMIC approach. Empirical Economics, Vol. 33. No. 1. 51-84. o. https://doi.org/10.1007/s00181-006-0084-3.

Dreher, A.-Schneider, F. [2006]: Corruption and the shadow economy: An empirical analysis. IZA Discussion Papers, No. 1936. https://www.econstor.eu/bitstream/10419/ 33465/1/51342489X.pdf.

Dreher, A.-SChneIder, F. [2010]: Corruption and the shadow economy: an empirical analysis. Public Choice, Vol. 144. No. 1-2. 215-238. o. https://doi.org/10.1007/s11127-0099513-0.

Dreher, A.-Kotsogiannis, C.-McCorriston, S. [2005]: How do institutions affect corruption and the shadow economy? International Tax and Public Finance, Vol. 16. No. 6. 773. o. https://doi.org/10.1007/s10797-008-9089-5.

Eco-Vista [2016]: Növekedési képességünk és a rejtett gazdaság. Eco-Vista Kft. https://www. parlament.hu/documents/126660/769617/N\%C3\%B6veked\%C3\%A9si+k\%C3\%A9pess\%C 3\%A9g\%C3\%BCnk+\%C3\%A9s+a+rejtett+gazdas\%C3\%A1g+(2016).pdf.

ÉKEs ILDIKó [2003]: A gazdaság árnyéka, avagy a rejtett gazdaság. Rejtjel Kiadó, Budapest. 
Enyedi György-TAmási PÉTer [1995]: A feketegazdaság: a piacgazdaság kísérőjelensége. Info-Társadalomtudomány, 33. sz. 3-6. o.

Feige, E. L. [1979]: How Big is the Irregular Economy? Challenge, Vol. 22. No. 5. 5-13. o. $10.1080 / 05775132.1979 .11470559$.

Fekete István-Ligeti CsÁk-PAtAky PéTer [2008]: A gazdaság kifehéredését vizsgáló bizottság jelentése. Kézirat, http://www.mkt.hu/docs/2008-02-18-11-58-01-a\%20feheredesrol_ 2008-02.pdf.

Gaspareniene, L.-Remeikiene, R. [2016]: The methodologies of shadow economy estimation in the world and in Lithuania: whether the criterions fixing digital shadow are included. Procedia Economics and Finance, Vol. 39. 753-760. o. https://doi.org/10.1016/s2212-5671(16)30277-5 .

Georgiu, M. N. [2013]: Shadow Economy and House Prices: A Panel Data Analysis in EU, USA, Japan. https://doi.org/10.2139/ssrn.2370424.

Glinkina, S. [1999]: Russia's Underground Economy During the Transition. Megjelent: Feige, E. L. $-O t t, K$. (szerk.): Underground Economies in Transition: Unrecorded Activity, Tax Evasion, Corruption and Organized Crime. Ashgate, Aldershot, 43-63. o.

Goel, R. K.-Saunoris, J. W.-Schneider, F. G. [2019]: Growth in the Shadows: Effect of the Shadow Economy on U.S. Economic Growth Over More than a Century. Contemporary Economic Policy, Vol. 37. No. 1. 50-67. o. https://doi.org/10.1111/coep.12288.

Johnson, S.-Kaufmann, D.-Zoido-Lobatón, P. [1998]: Regulatory Discretion and the Unofficial Economy. The American Economic Review, Vol. 88. No. 2. 387-392. o.

Kereszty BÉLA [1996]: Gazdasági bűnözés, feketegazdaság és a pénzmosás. Acta Universitatis Szegediensis: acta juridica et politica, 48. évf. 1-20. sz. 137-150. o.

Kirchgässner, G. [2016]: On Estimating the Size of the Shadow Economy. CESifo Working Paper, No. 5753. Center for Economic Studies and Ifo Institute (CESifo), München, http:// hdl.handle.net/10419/128456.

Kleven, H. J.-Knudsen, M. B.-Kreiner, C. T.-Pedersen, S. [2011]: Un-willing or Unable to Cheat? Evidence from a Tax Audit Experiment in Denmark. Econometrica, Vol. 79. No. 3. 651-692. o. https://doi.org/10.3982/ecta9113.

Krieenko, A.-Nevzorova, E. [2015]: Impact of Shadow Economy on Quality of Life: Indicators and Model Selection. Procedia Economics and Finance, Vol. 25. 559-568. o. https:// doi.org/10.1016/s2212-5671(15)00770-4.

KRISTON LÁszLó [2014]: Gazdaság, árnyékban. Piac és Profit, augusztus 23. https://piacesprofit. hu/gazdasag/gazdasag-arnyekban/2/.

Kucera, D.-Roncolato, L. [2008]: Informal employment: Two contested policy issues. International Labour Review, Vol. 147. No. 4. 321-348. o. https://doi.org/10.1111/j.1564913x.2008.00039.x.

LACKó MÁRIA [1995]: Rejtett gazdaság nemzetközi összehasonlításban. Közgazdasági Szemle, 42. évf. 5. sz. 486-510. o.

LACKó MÁRIA [2000]: Egy rázós szektor: a rejtett gazdaság és hatásai a posztszocialista országokban háztartási áramfelhasználásra épülő becslések alapján. Megjelent: Elemzések a rejtett gazdaság szerepéről. Mühelytanulmányok-sorozat. Tárki, Budapest.

LACKó MÁRIa [2006]: Az adóráták és a korrupció hatásai a munkapiacra. Keresztmetszeti összehasonlító elemzés az OECD-országokon. Közgazdasági Szemle, 53. évf. 11. sz. 961-985. o.

LACKó MÁria-Semjén András-Fazekas Mihály-Tóth István János [2009]: Rejtett gazdaság, rejtett foglalkoztatottság - kutatási eredmények és kormányzati politika a nemzetközi és hazai irodalom tükrében. Megjelent: Semjén András-Tóth István János (szerk.): Rejtett gazdaság. Benem jelentett foglalkoztatás ésjövedelemeltitkolás-kormányzati 
lépések és a gazdasági szereplők válaszai. MTA Közgazdaságtudományi Intézet, Budapest, 17-42. o. http://real.mtak.hu/81020/1/ktik11_05_hatter.pdf.

LoAyzA, N. V. [2016]: Informality in the process of development and growth. The World Economy, Vol. 39. 1856-1916. o. 10.1111/twec.12480.

Mack, C. [2016]: How to Write a Good Scientific Paper: Review Articles. Journal of Micro/ Nanolithography, MEMS, and MOEMS, Vol. 15. No. 2. 020101. https://doi.org/10.1117/1. jmm.15.2.020101.

Manolas, G.-Rontos, K.-Sfakianakis, G.-Vavouras, I. [2013]: The determinants of the shadow economy: The case of Greece. International Journal of Criminology and Sociological Theory, Vol. 6. No. 1. 1036-1047. o.

Mara, E. R. [2011]: Causes and consequences of underground economy. Annals. Economic Science Series, Vol. 17. 1109-1117. o.

Moher, D.-Cook, D. J.-Eastwood, S.-Olkin, I.-Rennie, D.-Stroup, D. F. [1999]: Improving the Quality of Reports of Meta-Analyses of Randomised Controlled Trials: The QUOROM Statement. British Journal of Surgery, Vol. 87. No. 11. 1448-1454. o. https://doi. org/10.1046/j.1365-2168.2000.01610.x.

Murai Bálint-Ritzlné Kazimir Ildikó [2011]: A nem megfigyelt gazdaság mérésének lehetőségei. Statisztikai Szemle, 89. évf. 5. sz. 502-521. o.

OECD [2002]: Measuring the Non-Observed Economy: A Handbook. OECD, Párizs, https:// doi.org/10.1787/9789264175358-en.

Pautasso, M. [2013]: Ten Simple Rules for Writing a Literature Review. PLoS Computational Biology, Vol. 9. No. 7. e1003149. https://doi.org/10.1371/journal.pcbi.1003149.

Pavicevic, R. [2014]: Tourism Destroys the Shadow Economy. CG Ekonomist online. http:// www.cgekonomist.com/?broj=12\&clanak=641\&lang=en.

Petreski, M. [2014]: Regulatory environment and development outcomes: empirical evidence from transition economies. Journal of Economic-Obsahyročníkov, Vol. 62. No. 3. 225-248. o.

SÁRKÁNY PÉTER [2014]: Illegális tevékenységek a svéd, a holland és a magyar statisztika alapján. Közgazdasági Szemle, 61. évf. 2. sz. 193-219. o. http://real.mtak.hu/17212/1/Kszemle_ CIKK_1455.pdf.

SCHNEIDER, F. [2007]: Shadow economies and corruption all over the world: new estimates for 145 countries. Economics, 2007-9. http://www.economics-ejournal.org/economics/ journalarticles/2007-9.

SchneIder, F. [2008]: Shadow Economy. Megjelent: Rowley, C. K.-Schneider, F. (szerk.): Readings in Public Choice and Constitutional Political Economy. Springer, New York, 511-532. o. https://doi.org/10.1007/978-0-387-75870-1_28.

Schneider, F. [2009]: Size and Development of the Shadow Economy in Germany, Austria and Other OECD Countries: Some Preliminary Findings. Revue Economique, Vol. 60. 1079-1116. o. https://doi.org/10.3917/reco.605.1079.

Schneider, F.-Enste, H. D. [2004]: The shadow economy: An international survey. Cambridge University Press, 56-89. o.

Schneider, F.-Williams, C. C. [2013]: The Shadow Economy. The Institute of Economic Affairs, London.

Schneider, F.-Buehn, A.-Montenegro, C. E. [2010]: New Estimates for the Shadow Economies all over the World. International Economic Journal, Vol. 24. No. 4. 443-461. o. https://doi. org/10.1080/10168737.2010.525974.

Schneider, F.-Buehn, A.-Montenegro, C. E. [2011]: Shadow economies all over the world: New estimates for 162 countries from 1999 to 2007. Megjelent: Schneider, F. (szerk.): 
Handbook on the Shadow Economy. Edward Elgar Publishing, Cheltenham, 9-77. o. https://doi.org/10.4337/9780857930880.00007.

Schneider, F.-Buehn, A.-Montenegro, C. E. [2011]: Shadow economies all over the world: New estimates for 162 countries from 1999 to 2007. Megjelent: Schneider, F. (szerk.): Handbook on the Shadow Economy. Edward Elgar Publishing, Cheltenham, 9-77. o. https://doi. org/10.4337/9780857930880.00007.

SEMJÉN ANDRÁs-Tóth István JÁnos [2004]: Rejtett gazdaság és adózási magatartás, 1996-2001. Közgazdasági Szemle, 51. évf. 6. sz. 560-583. o. http://real.mtak.hu/81116/ 1/Kszemle_CIKK_688.pdf.

SEMJÉn ANDRÁs-Tóth István János [2009]: Kormányzat és rejtett gazdaság - bevezető gondolatok. Megjelent: Semjén András-Tóth István János (szerk.): Rejtett gazdaság. Be nem jelentett foglalkoztatás és jövedelemeltitkolás - kormányzati lépések és a gazdasági szereplők válaszai. MTA Közgazdaságtudományi Intézet, Budapest, 9-14. o. http://www. econ.core.hu/file/download/ktik11/ktik11_04_bevezeto.pdf.

Sik ENDRE-Tóth István János [1998]: A rejtett gazdaság néhány eleme a mai Magyarországon. Megjelent: Kolosi Tamás-Tóth István György-Vukovich György (szerk.): Társadalmi riport. Tárki, Budapest, 92-116. o.

SisAK BALÁzs [2007]: Az árnyékos oldalon - a földalatti gazdaság mérete, kialakulásának indokai és hatásai. Acta Oeconomica Kaposváriensis, 1. évf. 1-2. sz. 55-164. o.

Smith, P. [1994]: Assessing the Size of the Underground Economy: the Canadian Statistical Perspectives. Canadian Economic Observer, No. 11. 16-33. o.

ŠTulhofer, A. [1999]: Between Opportunism and Distrust: Socio-Cultural Aspects of the Underground Economy in Croatia. Megjelent: Feige, E. L.-Ott, K. (szerk.): Underground Economies in Transition: Unrecorded Activity, Tax Evasion, Corruption and Organized Crime. Ashgate, Aldershot, 29-64. o. https://doi.org/10.4324/9780429021138-5.

SzÁntó Zoltán-Tóth István János [2001]: A rejtett gazdaság és az ellene való fellépés tényezői. Közgazdasági Szemle, 48. évf. 3. sz. 203-218. o. http://real.mtak.hu/92022/1/ szanto.pdf.

TAnZI, V. [1980]: The Underground Economy in the United States: Estimates and Implications. Banca Nazionale del Lavoro Quarterly Review, Vol. 135. No. 4. 427-453. o. https:// annalidibotanica.uniroma1.it/index.php/PSLQuarterlyReview/article/view/12996/12801.

Thiessen, U. [2010]: The shadow economy in international comparison: options for economic policy derived from an OECD panel analysis. International Economic Journal, Vol. 24. No. 4. 481-509. o. https://doi.org/10.1080/10168737.2010.525986.

Torgler, B.-Schneider, F. [2009]: The impact of tax morale and institutional quality on the shadow economy. Journal of Economic Psychology, Vol. 30. No. 2. 228-245. o. https://doi. $\operatorname{org} / 10.1016 /$ j.joep.2008.08.004.

Viksne, D.-Mazure, G. [2011]: Shadow Economy and its Relation to the Tax System of Latvia. Economic Science for Rural Development, Latvia University of Agriculture, Jelgava, 219-228. o.

VirTA, H. [2007]: Corruption and shadow economy: differences in the relationship between countries. Helsinki Center of Economic Research Discussion Paper, No. 171.

Webster, J.-Watson, R. T. [2002]: Analyzing the Past to Prepare for the Future: Writing a Literature Review. MIS Quarterly, Vol. 26. No. 2. 13-23. o. https://web.njit.edu/ egan/ Writing_A_Literature_Review.pdf.

Williams, C. C. [2004]: Cash-in-hand Work. The Underground Sector and the Hidden Economy of Favours. Palgrave Macmillan, Basingstoke. 